\title{
Proceeding
}

Supplementary Issue: Winter Conferences of Sports Science. Costa Blanca Sports Science Events, 22-23 March 2021. Alicante, Spain.

\section{An overview of the impact of the COVID-19 pandemic on sports industry: Causes, implications, and options}

\author{
BADR A. FALLATAH \\ Physical Education Department, Umm Alqura University, Saudi Arabia
}

\begin{abstract}
The effects of COVID-19 are being felt throughout the world's health, educational, financial, and commercial institutions, and the sports ecosystem is no exception. Matches and competitions are being cancelled or postponed, disrupting planning by governing bodies, organizers, teams and athletes - as well as non-stop live sports content we have come to expect. Owners, broadcasters, and sponsors are trying to navigate the impacts and implications of event cancellations and modifications. In a frenetic one-month period, countless sporting events - local, national or international - have been postponed at best or cancelled at worst. No sporting events were spared, even the Tokyo 2020 Olympic Games and the UEFA EURO 2020 have been postponed until 2021. The corona virus outbreak has left host cities in total disarray with no option but to revise their plans. More than $84 \%$ of host cities surveyed believe that COVID-19 has had a significant impact on all sports events planned for this year. However, when asked about the future, $58 \%$ think that the virus outbreak will only have a minor impact in 2021. In other words, host cities expect that things will soon get back to normal.
\end{abstract}

Keywords: Sports industry; COVID-19; Sports events; Football.

\section{Cite this article as:}

Fallatah, B.A. (2021). An overview of the impact of the COVID-19 pandemic on sports industry: Causes, implications, and options. Journal of Human Sport and Exercise, 16(3proc), S1094-S1103. https://doi.org/10.14198/jhse.2021.16.Proc3.26

Corresponding author. Physical Education Department, Umm Alqura University, Saudi Arabia.

E-mail: badrfallatah@gmail.com

Abstract submitted to: Winter Conferences of Sports Science. Costa Blanca Sports Science Events, 22-23 March 2021. Alicante, Spain.

JOURNAL OF HUMAN SPORT \& EXERCISE ISSN 1988-5202.

(c) Faculty of Education. University of Alicante.

doi:10.14198/jhse.2021.16.Proc3.26 


\section{INTRODUCTION}

Sports events have always been great platforms for host cities to achieve their broader goals. And the COVID-19 crisis can reinforce this catalytic effect. Whether it be for sports, branding, social or economic development, host cities still believe that sporting events will play an important role in overcoming the crisis. When asked for their opinion, host cities rated slightly higher the role that sporting events can play in social development.

Sporting events around the world are being postponed or cancelled by governing bodies in a bid to counter the spread of the corona virus. A range of sports have taken action, with the Football Association suspending the 2019-2020 professional football season, UEFA delaying Euro 2020 until the summer of 2021, and Formula 1 postponing a number of races with new race dates to be announced later in the 2020 season.

Similarly, Wimbledon has for the first time been cancelled since 1945 and the International Olympics Committee has decided to postpone the Tokyo 2020 Olympic Games to the summer of 2021. The new corona virus outbreak may also force host cities to review their hosting strategy. When asked about the impact that COVID-19 may have on the type of events to be hosted, cities are said to be planning fewer international sports events and more local or national sports events.

\section{IMPACT OF COVID-19 ON SPORT}

The COVID-19 pandemic has affected the EU and its Member States in a sudden and dramatic manner with unprecedented impact on the health and daily life of European citizens. The sport sector, including those who dedicate their lives (and often their businesses) to promoting health through physical activity, is profoundly worried about the wellbeing of people affected by the pandemic outbreak. The sport sector is eager to make its contribution towards the revival of what was once considered a normal way of life. Sport can help individuals and societies soften the negative effects of the current crisis on their lives through mechanisms that can contribute to people's health, socialization, education and a general sense of wellbeing. In addition to its disastrous short- and mid-term health impacts (including inactivity, mental health risks linked to loneliness and anxiety), apart from sport the pandemic will also have extraordinary long-term consequences on people's daily lives, health, and on societies in general and many sectors of the economy, especially service sectors such as tourism, food and accommodation services, transportation.

Sport in the Arab world largely relies on a fabric of small clubs and associations which play a key role in allowing so many citizens to take part in affordable sport activities and to enjoy sport and physical activities on a daily basis. These small clubs and associations are the backbone of sport in the region. However, being non-profit by nature and thus without any reserves, they often function in precarious conditions, driven by the support of passionate volunteers and employees. In sport, especially at grassroots level, this economic crisis has led to the bankruptcy of associations and clubs that promote physical activity and offer affordable sport activities to citizens across the Middle East.

Consequently, the sport sector is also set to face an unemployment emergency. These smaller grassroots associations are at the greatest risk of shutting down due to the crisis, which could have a number of longlasting impacts on the economy and society, not to mention endangering the future of all grassroots sports in the Middle East. 


\section{SPREAD OF COVID-19}

Real-time data on the spread of the corona virus (or Covid-19 disease) was collected from the World meter. The data shows that the US has the highest number of infected individuals, followed by China, Italy and Iran as of April 23, 2020. These statistics are reported in Table 1.

Table 1. COVID-19 statistics (as at 23rd April).

\begin{tabular}{lccc}
\hline Countries & Confirmed Cases (Total) & Confirmed Deaths(Total) & Recovered (Total) \\
\hline Global & 2.656 .391 & 185.156 & 729.815 \\
US & 849.092 & 47.681 & 84.050 \\
Italy & 187.327 & 25.085 & 54.543 \\
China & 82.798 & 4.632 & 77.207 \\
Iran & 87.026 & 5.481 & 64.477 \\
Spain & 213.024 & 22.157 & 89.250 \\
Germany & 150.729 & 5.315 & 103.300 \\
UK & 133.495 & 18.000 & - \\
Canada & 40.190 & 1.974 & 13.986 \\
France & 159.877 & 21.340 & 40.657 \\
India & 21.797 & 681 & 4.376 \\
South Korea & 10.702 & 240 & 8.411 \\
Turkey & 98.674 & 2.376 & 16.477 \\
Russia & 62.773 & 555 & 4.891 \\
Brazil & 46.182 & 2.924 & 25.318 \\
South Africa & 3.635 & 65 & 1.055 \\
Nigeria & 873 & 28 & 197 \\
Tunisia & 909 & 38 & 190 \\
\hline
\end{tabular}

Source: Worldometer. 5 Note that there may be unconfirmed cases which were never reported to the public health authorities.

Regional data on the spread of the corona virus (or Covid-19 disease) which was reported by the World Health Organization show that Europe has the highest number of infected cases, followed by the region of the Americas, and the Eastern Mediterranean as of April 23, 2020. These statistics are reported in Table 2.

Table 2. World Region Situation in Numbers as of 23rd April 2020.

\begin{tabular}{lcccc}
\hline Region & Confirmed Cases & New Cases & Total Deaths & New Deaths \\
\hline Global & 2.471 .136 & 73.920 & 169.006 & 6.058 \\
European region & 1.219 .486 & 32.302 & 109.952 & 3.618 \\
Region of the Americas & 925.291 & 32.172 & 44.775 & 2.089 \\
Eastern Mediterranean & 139.349 & 4.879 & 6.326 & 141 \\
Western Pacific Region & 136.271 & 1.765 & 5.793 & 108 \\
Southeast Asia & 33.912 & 2.242 & 1.427 & 86 \\
African region & 16.115 & 560 & 720 & 16 \\
\hline \multicolumn{5}{l}{ Source: World Health Organisation. }
\end{tabular}

To safeguard the health of athletes and others involved, most major sporting events at international, regional and national levels have been cancelled or postponed - from marathons, football tournaments, and athletics championships to basketball games, handball, ice hockey, rugby, cricket, sailing, skiing, weightlifting, 
wrestling and more. For the first time in the history of the modern games, the Olympics and Paralympics have been postponed until 2021.

The global value of the sports industry is estimated at US\$756 billion annually. In the face of COVID-19, many millions of jobs are therefore at risk globally, not only for sports professionals but also for those involved in related retail and sporting services industries connected with leagues and events, which include travel, tourism, infrastructure, transportation, catering, media broadcasting, among others. Professional athletes are also under pressure to reschedule their training while trying to stay fit at home or risk losing professional sponsors who may not support them anymore as initially agreed.

In addition to economic repercussions, the cancellation of games also undermines many social benefits of global and regional sport events which can cement social cohesion, contribute to the social and emotional excitement of fans, as well as their identification with athletes leading to greater physical activity among individuals. Sport has long been considered a valuable tool for fostering communication and building bridges between communities and generations. Through sport, various social groups are able to play a more central role in terms of social transformation and development, particularly in societies that are divided. Within this context, sport is used as a tool for creating learning opportunities and ensuring access to often marginal or at-risk populations.

The sports industry has been severely affected by this corona virus outbreak. In the football segment, major European football leagues in England and Scotland have announced the immediate suspension of all football matches for 6 weeks until April 30.

The Turkish super league was the last major European league to suspend its matches. In Formula One, the Monaco Grand Prix was cancelled.

The Tokyo Summer Olympic and Paralympics games were also postponed. As to hockey, the 2020 hockey season in England has been postponed. England's FIH Pro League games scheduled for May 2-3 and 1617 have also been postponed. In rugby, the Pro14 final scheduled for June 20 at the Cardiff City Stadium was cancelled. Major league rugby (MLR) has also been cancelled for the remainder of the 2020 season. In the baseball segment, all major baseball league season games were called off in Mexico and Puerto Rico. Motorsport in Portugal was postponed after the Portuguese Government declared a state of emergency and suspended all sporting events in the country.

In the snooker segment, the world snooker championship to be held in Sheffield from April 18 to May 4 was postponed. As far as swimming is concerned, the 2020 European Aquatics Championship scheduled for the 11th to 24th in Hungary has been postponed until August. In the golf segment, the "LPGA" tour was rescheduled for September 10-13, 2020. The resulting loss in revenue to sponsors and organizers of all these cancelled games ran into billions of dollars.

The macroeconomic slowdown has also led to a rise in nonperforming loans in the banking sector by 250 basis points. Private sector banks had the highest exposure to credit risk during the outbreak. Nonperforming loans have to do with loans issued to small and medium scale enterprises (SMEs), airlines, hotels, tour operators, restaurants, retail, construction and real estate businesses. During the pandemic, there was a general decline in the volume of bank transactions, fewer card payments, and a fall in the use of ATM cash machines worldwide. This led to fewer fees collected by banks which negatively affected their profit. FinTech businesses were also affected. Some FinTech businesses witnessed very low patronage by consumers, 
leading to loss of revenue and profits which negatively affected the equity investment of venture capitalists that funded existing and new FinTech firms.

This made many venture capitalists begin to hoard new equity which led to the drying up of financing for some FinTech businesses. On the other hand, the lockdowns due to the corona virus outbreak resulted in higher demand for some other online services such as online shopping.

During the corona virus outbreak, the events industry was hit by a large number of cancellations-exhibitions, live music shows, conferences, weddings, parties, corporate events, brand launches, trade shows, and more. Several other big events were cancelled; for instance, the E3 and SXSW tech events were cancelled which led to direct losses of more than US\$1 billion. Informa delayed or cancelled events worth $£ 400 \mathrm{~m}$ due to the pandemic. The 2020 Met Gala was postponed indefinitely. In the US, many big event management companies that were hit financially by the corona virus outbreak appealed for federal aid. The industry's event ticketing segment was also affected. One of the biggest global ticketing and events companies, 'Eventbrite', announced that the COVID-19 outbreak negatively affected its business outlook for 2020. The effect of increasing cancellations on Eventbrite was so bad that the company had to withdraw its previously published 'positive outlook' for the first quarter of 2020. The effect of the outbreak on global live events was worsened by the social distancing policy imposed by many governments.

\section{FOOTBAL \& COVID-19}

There are a number of regulatory considerations for English football clubs that are experiencing financial difficulties on account of COVID-19. For football clubs that end up in an insolvency process, consideration should be given to the football creditors' rule.

The football creditors' rule is specific to insolvency events affecting a football club (or its parent undertaking) which is a member of the Premier League or a football club (or its parent undertaking or subsidiary of its parent undertaking) which is a member of the "EFL".

The football creditors' rule effectively prioritizes payments to certain football related creditors ahead of other creditors by requiring these football clubs to pay them. Football clubs may also be contemplating whether to obtain shareholder funding to make up for the loss of income streams as a result of COVD-19. Football clubs should consider the regulations relating to financial fair play in the applicable "PL Rules, EFL Rules and/or UEFA - Club Licensing and Financial Fair Play Regulations 2018". Each of the aforementioned rules provide for various restrictions on the aggregate number of losses a participating club is permitted to make over a prescribed period of time. Under those rules, clubs are required to demonstrate they have satisfactory shareholder funding in place to cover losses in the event they reach a certain threshold. Both the PL Rules and "EFL" Rules prescribe how shareholder funding should be structured for it to be able to qualify for covering losses of any relevant club. Penalties for noncompliance include, among other things and as applicable, exclusion from UEFA competitions, suspension from playing league matches, and points deductions.

\section{LITERATURE REVIEW}

In 2019, there was concern over the effect of Brexit, the US Presidential elections, and a trade war between China and America on the global economy. Due to fright and doubt, and to reasonable estimation that 
companies' profits are likely to be reduced due to the effect of COVID-19, stock markets worldwide eliminated about US\$6 trillion in wealth during the week of February 24-28.

In the same week, the S\&P 500 index missed over $\$ 5$ trillion of value in the US, while the S\&P 500's largest 10 firms reported loss of over $\$ 1.4$ trillion even though some of these were recuperated in the week that followed. Some of the loss in value was according to reasonable estimation by investors whose companies' profits might come down due to the effect of the corona virus (Radelet and Elliot, 2020).

The International Air Transportation Association (IATA) estimated that the air travel industry could lose US $\$ 113$ billion if the COVID-19 outbreak were not quickly brought under control. The IMF reduced their growth expectation for the world economy as the COVID-19 outbreak threw their earlier expectation into serious doubt. The tourism industry was also impacted as travel opportunities for Chinese tourists, who would normally spend billions each year, were strictly curtailed (El-Erian, 2020).

An increased number of flights was called off, so did hotel bookings and local or international events worth over $\$ 200$ billion. The flow of goods through global supply chains vastly decreased since China, the world's largest manufacturer and exporter, ordered the closure of major factories in the country (Bentolila et al, 2018).

In March of this year, the International Monetary Fund announced that it anticipated a global recession which would be at least as bad as the 2007-2008 global financial crisis, followed by a recovery in 2021 (Georgieva, 2020).

The literature on the cause of recessions is vast (see Jagannathan et al, 2013; Stiglitz, 2010; Gaiotti, 2013; Bezemer, 2011; Mian and Sufi, 2010; Bentolila et al, 2018; Bagliano and Morana, 2012). But the cause of the 2020 global recession is novel in terms of modern history. The corona virus triggered a new type of recession that was different from triggers of past recessions.

For instance, the Asian debt crisis of 1997 was caused by the collapse of the Thai baht in July 1997, which created panic that caused a region-wide financial crisis and economic recession in Asia (Radelet and Sachs, 1998).

The 2008 global financial crisis, which translated to a recession, was caused by a loose monetary policy which created a bubble, followed by subprime mortgages, weak regulatory structures, and high leverage in the banking sector (Allen and Carletti, 2010).

The 2016 recession in Nigeria was caused by a fall in the price of crude oil, balance of payment deficit, adoption of a fixed-float exchange rate regime, an increase in the pump price of petrol, activities of pipeline vandals, and infrastructure weaknesses. The 2010 recession in Greece was caused by the after-effect of the global financial crisis, structural weaknesses in the Greek economy, and a lack of monetary policy flexibility as a member of the Euro Zone (Rady, 2012).

Initially, the perception was that the COVID-19 pandemic would be localized in China. It later spread across the world through the movement of people. The economic pain became severe as people were asked to stay at home, and the severity was felt in various sectors of the economy with travel bans affecting the aviation industry, sporting event cancellations affecting the sports industry, and prohibition of mass gatherings affecting the events and entertainment industries (Horowit, 2020). 
There are parallels between the COVID-19 crisis and the events of 2007-2008: as in 2020, many people in the 2007-2008 recession assumed the impacts would largely be localized (in that case based on an assumption that the subprime mortgage crisis would be a relatively minor problem affecting only the US, but it ultimately affected the entire global financial system) (Elliot, 2020).

The sudden economic disruption caused by COVID-19 is not only destructive but also has spill over implications because it created demand and supply shocks in almost every area of human endeavour (ElErian, 2020).

\section{DISCUSSION}

This survey's results show that cities unanimously expect the COVID crisis to have important and immediate negative repercussions on their hosting of sporting events, some even predict that the financial impact of the crisis will last beyond 2021.

The current epidemic outbreak is as serious as it was sudden and unexpected for the world of sports. While it will undeniably have a strong impact on cities' hosting strategies going forward, sports will learn from this challenge and will emerge stronger than before with the necessary tools in hand to confront future challenges that may come its way.

With revenue streams disrupted by the suspension or cancellation of matches and competitions, many governing bodies are continuing to monitor developments to see whether they can provide support. The RFU, for example, is investigating options to provide support to clubs and are in close contact with the UK Government to obtain further details on how recent measures might benefit rugby clubs. Other governing bodies have taken quicker action. The "EFL" are putting measures in place to immediately assist clubs with cash flow problems by setting up a GBP 50 million short term relief package.

The fund consists of the remaining Basic Award payments being advanced to clubs immediately, with the remainder to be made through interest free-loan facilities available to clubs.

When public health officials determine that the outbreak has ended in the local community, the Outdoor Team Sporting Industry will consult with relevant authorities to identify criteria for scaling back its COVID-19 prevention actions. The Outdoor Team Sporting Industry will also determine which protocols should remain so as to optimize public health.

At this time, the Q/Sport Outdoor Team Sporting group will consult with key stakeholders to review the delivery of its return to sporting arrangements and use feedback to improve organizational plans and systems.

Governments should work collaboratively with health and care services, schools and civil society organizations representing various interest groups in order to support physical activity at home. Enhancing access to online resources with a view to facilitating sport activities where available should be a key goal in order to enhance social distancing. However, low-tech and no-tech solutions must also be sought for those who currently lack access to the internet. Creating a flexible but consistent daily routine including daily physical exercise to help with stress and restlessness is advisable. 


\section{CONCLUSION}

We analysed the corona virus outbreak and spill over to the global economy that triggered the 2020 global recession. Policy makers in many countries were under pressure to respond to the corona virus outbreak. As a result, many governments made swift policy decisions that had far-reaching positive and negative impacts on their respective economies, with many countries plunging into recession. Social distancing policies and lockdown restrictions were imposed in many countries despite the fact that many have argued that such social policies may trigger a recession.

Lawmakers in many countries supported an extended social distancing policy, with damning consequences for the economy. The recession that followed, which many countries experienced, was a reflection of the difficult choice that policy makers had to make between choosing to save the economy or to save people; many countries chose the latter. There were criticisms that the adopted policies were too quick, premature or inadequate.

Others argued that the policies contradicted one another in some areas; for instance, the accommodative monetary policy encouraged economic agents to engage in economic activities while the lockdowns and social distancing (stay-at-home) policy prevented economic activities from taking place.

On the bright side, the corona virus-induced public health crisis created an opportunity for many governments to make lasting reforms in the public health sector. Countries like the UK and Spain repaired their public health care system, and fixed other shortcomings in public infrastructure such as the transition to online education, transportation systems and disease-detection systems in their public hospitals.

Some governments also used the crisis as an opportunity to fix the economic and financial systems with a stimulus package.

Our study has certain limitations. The main limitation is the short period under analysis due to a limited dataset. A longer study period may better capture the socioeconomic consequences of government policies during the corona virus crisis. Moreover, as future events unfold, there could be spill overs to other sectors that we have not analysed in this study. Future studies on spill overs could be extended in two directions. First, future studies can examine the impact of government policies on the informal economy. Second, they could also explore how banks and financial institutions react to economic policy developments during the current crisis.

In these exceptional circumstances, it is important to establish quick and adequate support and a clear action plan to mitigate the adverse effects of the current COVID-19 crisis on the sports sector. EU member states are currently discussing possible ways of reallocating some of the European Structural and Investment Funds to address the ramifications of the present crisis.

Supportive measures should notably include the following:

- Ensuring that the sport sector is eligible to funds for the protection of jobs, employees and selfemployed against the risk of dismissal and loss of income.

- Relaxing the rules relating to state aid, as is already the case in other sectors, with a view to allowing tax breaks for entities and organisations that promote sport activities.

- Stimulating innovation programmes (industrial modernisation) for sport enterprises to address the current societal challenges. 
- Providing loans to ensure the liquidity of sport clubs and other associations through existing EU financial instruments (e.g., European Investment Bank) or newly created instruments as a response to this crisis.

- Redirecting certain EU and national funding streams, notably the European Structural and Investment Funds, towards actions promoting the wellbeing of citizens through sport and physical activity.

- Setting up public and private solidarity funds for grassroots sport clubs and associations and their employees, including outsourced coaches and freelancers who are self-employed persons.

- Creating new funding opportunities as innovative ways to promote sport and physical activity in times when people are restricted to their homes.

- Helping schools and physical education teachers to continue training pupils through digital means that are effective and safe (and stimulate innovation), i.e., through funding, guidelines, best practice cases, internet price concessions. And ultimately, stimulating a healthy active lifestyle among the working population, both those working at home and at the office by introducing innovative solutions to stimulate physical activity.

\section{REFERENCES}

Allen, F., \& Carletti, E. (2010). An overview of the crisis: Causes, consequences, and solutions. International Review of Finance, 10(1), 1-26. https://doi.org/10.1111/i.1468-2443.2009.01103.x

Bagliano, F. C., \& Morana, C. (2012). The Great Recession: US dynamics and spillovers to the world economy. Journal of Banking \& Finance, 36(1), 1-13. https://doi.org/10.1016/i.jbankfin.2011.06.002

Bentolila, S., Jansen, M., \& Jiménez, G. (2018). When credit dries up: Job losses in the great recession. Journal of the European Economic Association, 16(3), 650-695. https://doi.org/10.1093/jeea/jvx021

Bezemer, D. J. (2011). The credit crisis and recession as a paradigm test. Journal of Economic Issues, 45(1), 1-18. El-Erian, M. (2020). https://doi.org/10.2753/JEI0021-3624450101

Financial Times (2020). The Coming Coronavirus Recession and the Uncharted Territory Beyond. Foreign Affairs, Media Report. Available at: https://www.foreignaffairs.com/articles/2020-0317/coming-coronavirus-recession

Gaiotti, E. (2013). Credit availability and investment: Lessons from the "great recession." European Economic Review, 59, 212-227. https://doi.org/10.1016/i.euroecorev.2012.12.007

Georgieva, K (2020). IMF Managing Director Kristalina Georgieva's Statement Following a G20 Ministerial Call on the Coronavirus Emergency. IMF Press statement. Available at: https://www.imf.org/en/News/Articles/2020/03/23/pr2098-imf-managing-director-statementfollowing-a-g20-ministerial-call-on-the-coronavirus-emergency

Gaiotti, E. (2013). Global recession already here, say top economists. Available at: https://www.ft.com/content/be732afe-6526-11ea-a6cd-df28cc3c6a68

Horowit, J. (2020). The global coronavirus recession is beginning. CNN. Media report. Available at: https://edition.cnn.com/2020/03/16/economy/global-recession-coronavirus/index.html

Jagannathan, R., Kapoor, M., \& Schaumburg, E. (2013). Causes of the great recession of 2007-2009: The financial crisis was the symptom not the disease. Journal of Financial Intermediation, 22(1), 429. https://doi.org/10.1016/i.jfi.2012.06.002

Larry Elliot, L. (2020). Prepare for the coronavirus global recession. The Guardian. Media report. Available at: https://www.theguardian.com/business/2020/mar/15/prepare-for-the-coronavirusglobal-recession 
Mian, A., \& Sufi, A. (2010). The great recession: Lessons from microeconomic data. American Economic Review, 100(2), 51-56. Ozili, P. K. (2019). 100 Quotes from the Global Financial Crisis: Lessons for the future. Available at SSRN 3500921. https://doi.org/10.1257/aer.100.2.51

Radelet, S., \& Sachs, J. (1998). The onset of the East Asian financial crisis (No. w6680). National bureau of economic research. https://doi.org/10.3386/w6680

Rady, D. A. M. (2012). Greece debt crisis: Causes, implications and policy options. Academy of Accounting and Financial Studies Journal, 16, 87.

Stiglitz, J. E. (2010). Interpreting the Causes of the Great Recession of 2008. Financial system and macroeconomic resilience: revisited. Bank for International Settlements. 